\title{
COMPARISON BETWEEN INDIVIDUAL AND GROUP MATING \\ OF AUSTROPOTAMOBIUS PALLIPES UNDER CONTROLLED CONDITIONS
}

\author{
M. SÁEZ-ROYUELA*, J. M. CARRAL, J. D. CELADA, P.M. MELENDRE, A. AGUILERA
}

Departamento de Producción Animal II. Facultad de Veterinaria. Universidad de León. Campus de Vegazana s/n. 24071 León, Spain.

E-Mail: dp2msg@unileon.es

Reçu le 19 octobre 2004

Received October 19, 2004

Accepté le 3 janvier 2005

Accepted January 03, 2005

\begin{abstract}
Individual mating was compared with mating in groups under laboratory conditions using 64 females and 32 males of white-clawed crayfish (Austropotamobius pallipes). Mating in groups took place at a density of 24 animals $/ \mathrm{m}^{2}$ placed in two $1 \mathrm{~m}^{2}$ fibreglass tanks (16 females and 8 males/tank). Individual pairing was made in net plastic cubic boxes of $0.25 \times 0.25 \mathrm{~m}$ bottom surface placed in $1 \mathrm{~m}^{2}$ fibreglass tanks ( 8 boxes/tank). Percentages of mating and spawning were similar in both treatments (100 and 93.7\% in groups and 96.9 and $93.7 \%$ in individual pairing). However, pleopodal egg number and survival rate 78 days after spawning (phase VIII-IX of embryonic development) were higher in females mated in groups (67 and 57.4\%) than those individually inseminated (26 and $25.9 \%$ ). Possible causes of lower egg survival rate of individually mated females are discussed.
\end{abstract}

Key-words: astacid white-clawed crayfish, reproduction.

\section{COMPARAISON ENTRE ACCOUPLEMENTS INDIVIDUELS ET EN GROUPES CHEZ AUSTROPOTAMOBIUS PALLIPES SOUS CONDITIONS CONTRÔLÉES}

\section{RÉSUMÉ}

L'accouplement individuel a été comparé avec l'accouplement en groupes sous conditions de laboratoire. Pour cela on a utilisé 64 femelles et 32 mâles d'écrevisses à pattes blanches (Austropotamobius pallipes). L'accouplement en groupes a eu lieu à une densité de 24 animaux $/ \mathrm{m}^{2}$ placés dans deux tanks de fibre de verre d' $1 \mathrm{~m}^{2}, 16$ femelles et 8 mâles/tank. L'accouplement individuel a été accompli dans des boîtes cubiques de $0,25 \times 0,25 \mathrm{~m}$ faites d'une maille plastique et placées dans un tank de fibre de verre (8 boîtes/tank). Les pourcentages d'accouplement et de ponte ont été similaires dans les deux traitements (100 et 93,7 \% en groupes et 96,9 et 93,7 \% en accouplement individuel). Cependant, le nombre des œufs pléopodaux et les taux de survie 78 jours après la ponte (phase VIII-X du développement embryonnaire) ont été plus élevés chez les femelles accouplées en groupes (67 et 57,4\%) que chez celles inséminées individuellement (26 et $25,9 \%$ ). Les causes possibles d'un taux de survie inférieur avec accouplement individuel sont débattues.

Mots-clés : astacidé écrevisse à pattes blanches, reproduction. 


\section{INTRODUCTION}

In natural populations, WOODLOCK and REYNOLDS (1988) observed that polygamy is a very common fact in Austropotamobius pallipes. This has also noted by HESSEN et al. (1989) in Astacus astacus.

In captivity, white-clawed crayfish of both sexes are polygamous (REYNOLDS et al., 1992), with frequent multiple matings. In this sense, WOODLOCK (1985) reported more than 8 copulations for the same male and, in single couples, a maximum of 5 matings in two hours. In the same way, INGLE (1977) observed a female inseminated by 5 males consecutively. Similar observations have been reported in other species. According to CUKERZIS (1984), male noble crayfish did not mate more than 2 or 3 times consecutively. However SVENSSON and GYDEMO (1997) stated that single male noble crayfish with a carapace length of $10 \mathrm{~cm}$ and larger can mate with 15-30 females.

Taking into account this reproductive pattern is a common practice to keep broodstock in groups more or less numerous for mating and spawning under controlled conditions (PURSIAINEN et al., 1989; TAUGBØL and SKURDAL, 1990; CARRAL et al., 1994). As few studies have been performed with single couples (WOODLOCK and REYNOLDS, 1988; MATTHEWS, 1992) and no comparisons have been made between these two possibilities, the aim of this paper is to know the effects of individual mating on further pleopodal egg production.

\section{MATERIAL AND METHODS}

64 adult females and 32 males of white-clawed crayfish (A. pallipes) from the same population were individually marked following the system used by ABRAHAMSSON (1995) and moved under laboratory facilities. Aerated water from a deep artesian well was used in a flow-through system, with a flow rate of 1 litre per minute. Crayfish were maintained under natural light conditions and fed with wheat grains and pork liver twice a week. Water temperature (Figure 1) was not modified during the experimental period.

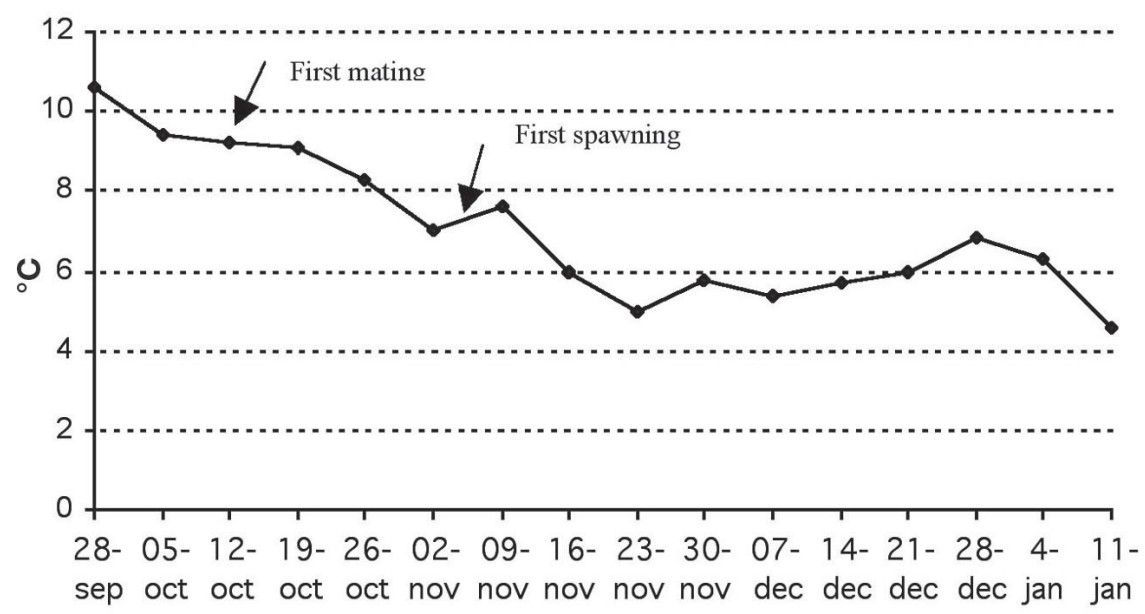

Date

\section{Figure 1}

Mean water temperature throughout the experimental period.

\section{Figure 1}

Température moyenne de l'eau tout au long de la période expérimentale. 


\section{Two mating conditions were compared:}

1) GROUP MATING: 32 females (mean carapace length $=37.37 \pm 0.04 \mathrm{~mm}$ ) and 16 males (mean carapace length $=45.37 \pm 0.54 \mathrm{~mm}$ ) were distributed in two fibreglass tanks ( $1 \mathrm{~m}^{2}$ surface) at a density of $24 \mathrm{crayfish} / \mathrm{m}^{2}$. Each tank was provided with shelters consisting in two pairs of fibrocement plates $(50 \times 25 \mathrm{~cm})$ and 10 PVC pipes (length: $15 \mathrm{~cm}$; diameter; $5 \mathrm{~cm}$ ).

2) INDIVIDUAL MATING: 16 net plastic cubic boxes $(0.25 \times 0.25 \times 0.40 \mathrm{~m})$ were placed in two fibreglass tanks ( $1 \mathrm{~m}^{2}$ surface). A male and a female were introduced in each box. After insemination, the female was replaced by another unmated female. Mean carapace length was $34.36 \pm 0.07$ and $41.92 \pm 0.83 \mathrm{~mm}$ for females and males, respectively. Each box was provided with one PVC pipe as described above as shelter.

During the mating period, all females were checked every three days for the presence of white spermatophores and the successfully mated ones were removed and placed in six spawning tanks, with the same kind and number of shelters as those used in group mating.

Pleopodal eggs were counted without removal 4-10 days after spawning and afterwards every 13 days until they reached the embryonic phase VIII-IX (embryo with mandibular anlagen-embryo with naupliar appendages), 78 days after spawning. The phase of embryonic development was determined by means of techniques developed by CELADA et al. (1985), and CELADA, CARRAL and GONZÁLEZ (1991). Survival rate was calculated as percentage of eggs between embryonic phases VIII and IX from initial number. When males and females were kept in couples, efficiency rates between the first and the second copulation by the male were compared.

Data were examined by ANOVA performed with the software Statistica 6.0. (Statsoft, Inc., Tulsa, Oklahoma, USA). The significance level was $\mathrm{P}<0.05$.

\section{RESULTS}

In both experimental groups, the first mating was recorded on 13 October (water temperature: $9^{\circ} \mathrm{C}$ ) and the last one on 3 November, for females individually mated, and three days later for those kept in groups. Therefore, mating period lasted 21 days when broodstock was maintained in couples and 25 when they were in groups. First spawning was observed on 7 and 8 November, when pairing took place individually and in group, respectively, at a water temperature of $7^{\circ} \mathrm{C}$. Spawning period was 21 days for females mated in pairs and 6 days for those inseminated in groups.

Mating and spawning percentages were high in both cases (Table I). In individual mating, only one male did not mate with the second female.

Number of eggs in the different counts (Figure 2) was significantly higher when copulation took place in groups. The egg survival rate at the end of the experiment (phase VIII-IX; 78 days after spawning) was therefore better than in individual mating (Table I).

When males and females were kept in couples, mean efficiency rate for the first mating was significantly higher $(40.8 \pm 10.6 \%)$ than for the second one $(11.7 \pm 6.7 \%)$. The females inseminated by five of the sixteen males lost all pleopodal eggs before reaching the stage VIII-IX.

In both mating conditions, the main egg losses occurred in the earlier stages of embryogenesis (phases III-the blastosphere and IV-embryo with entodermal disc, mesoderm formative zone, cephalic lobes and thoracic-abdominal plates). 


\section{Table I}

Percentages of mating, spawning and egg survival at phase VIII-IX of embryonic development. Values followed by differing letters were significantly different $(P<0.05)$ from the others in the same column.

\section{Tableau I}

Pourcentages d'accouplement, de ponte et de survie à la phase VIII-IX du développement embryonnaire. Les valeurs suivies de lettres différentes étaient sensiblement différentes $(P<0,05)$ des autres valeurs dans la même colonne.

\begin{tabular}{lccc}
\hline & Mating (\%) & Spawning (\%) & $\begin{array}{c}\text { Survival rate (\%) at phase VIII-IX } \\
(\text { mean } \pm \text { MSE) }\end{array}$ \\
\hline GROUP & 100 & 93.7 & $57.4 \pm 6.3^{\mathrm{a}}$ \\
\hline INDIVIDUAL & 96.9 & 93.7 & $25.9 \pm 6.5^{\mathrm{b}}$ \\
\hline
\end{tabular}

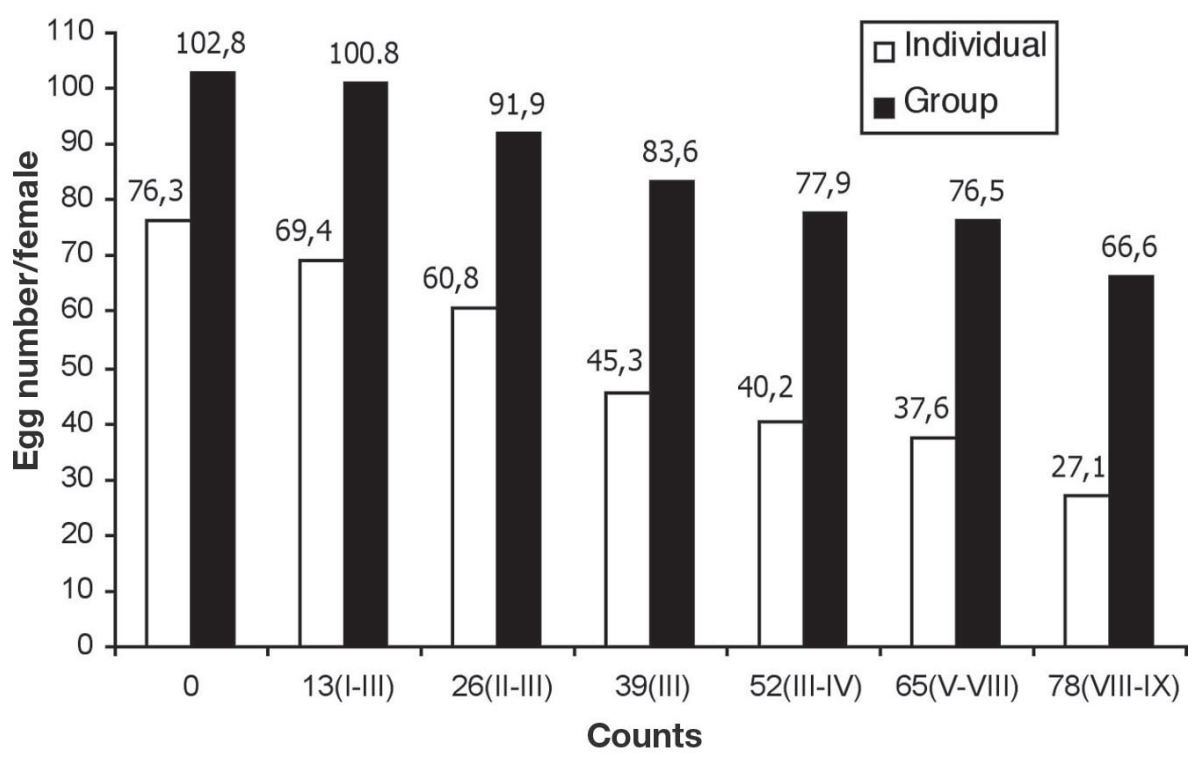

Figure 2

Mean number of pleopodal eggs in individual and group mating.

Figure 2

Nombre moyen d'œufs pléopodaux dans les accouplements individuels et de groupe.

\section{DISCUSSION}

INGLE (1977) and WOODLOCK and REYNOLDS (1988) stated that in captive A. pallipes matings occurred several days earlier when higher densities were involved. In our study first copulation was recorded at the same day when crayfish were maintained in groups or in couples and the duration of mating period was similar in both cases. However, spawning period for females individually inseminated was exceptionally extended ( 21 days) when compared to data reported by REYNOLDS et al. (1992) of 46 days after mating. 
From the results it seems to be that mating and spawning are not negatively affected by maintaining females with one single male. However, the initial number of pleopodal eggs was lower in this case. Although the number of eggs is positively correlated to size (RHODES and HOLDICH, 1982; BREWIS and BOWLER, 1985; CARRAL et al., 1994), the small difference in mean $C L$ of females of the two experimental groups cannot explain this lower fecundity. Considering that pleopodal attachment at spawning is a critical period for egg survival (REYNOLDS et al., 1992), undetected loss of eggs could have took place before the first check. The differences between egg survival rates in both treatments could be attributed to the total egg losses detected in ten of the thirty-two females individually mated. Taking into account that five males inseminated these females, we hypothesize that low fertility or infertility of males can have a negative effect when pairing take place in couples.

In previous studies with A.pallipes (CARRAL et al., 2000; CELADA et al., 2001), heavy losses were recorded during the first period of embryogenesis. In our experiment, most of egg mortality took place before gastrulation (phase V). In females individually mated, they occurred mainly during the first 39 days after spawning (phase III, the blastosphere) and, at this time, total egg losses were recorded in six females. Similar observations were made in other laboratory studies (REYNOLDS et al., 1992), where A.pallipes eggs developed normally to stage III and then failed to progress further.

SVENSON and GYDEMO (1997) reported up to 42 copulations by the same A.astacus male and REYNOLDS et al. (1992) up to 8 in A. pallipes, but data about the effects on the further embryonic development were not provided. In our trial, second mating in individual couples resulted on significantly lower efficiency rate.

The results obtained led us to consider, according to MATTHEWS (1992), that holding crayfish in groups has a positive influence on $A$. pallipes eggs fertilization, as this reproductive pattern could allow for the possibility of sperm contribution from several males.

\section{REFERENCES}

ABRAHAMSSON S.A.A., 1965. A method of marking Astacus astacus Linné in population studies. Oikos, 16, 228-231.

BREWIS J.M., BOWLER K., 1985. A study of reproductive females of the freshwater crayfish A. pallipes. Hydrobiologia, 121, 145-149.

CARRAL J.M., CELADA J.D., GONZÁLEZ J., SÁEZ-ROYUELA M., GAUDIOSO V.R., 1994. Mating and spawning of freshwater crayfish Austropotamobius pallipes Lereboullet, under laboratory conditions. Aquaculture and Fisheries Management, 25, 721727.

CARRAL J.M., CELADA J.D., MUÑOZ C., SÁEZ-ROYUELA M., PÉREZ J.R., 2000. Effects of the presence or absence of males throughout spawning and maternal incubation on the reproductive efficiency of astacid crayfish (Austropotamobius pallipes) under controlled conditions. Invertebr. Reprod. Dev., 38 (1), 1-5.

CELADA J.D., CARRAL J.M., GONZÁLEZ J., 1991. A study on the identification and chronology of the embryonic stages of the freshwater crayfish Austropotamobius pallipes (Lereboullet, 1858). Crustaceana, 61, 3, 225-232

CELADA J.D., CARRAL J.M., SÁEZ-ROYUELA M., MUÑOZ C., PÉREZ J.R., 2001. Effects of different thermal treatments on the maternal incubation efficiency of the astacid crayfish Austropotamobius pallipes (Lereboullet, 1858) under controlled conditions. Crustaceana, 74 (9), 801-808. 
CELADA J.D., GAUDIOSO V.R., DE PAZ P., FERNÁNDEZ R., 1985. Identification et chronologie des phases de developpement des œufs de l'écrevisse (Pacifastacus leniusculus Dana) par l'observation directe. La Pisciculture Française, 82, 5-8.

CUKERZIS J.M., 1984. La biologie de l'écrevisse (Astacus astacus L.). INRA, Versailles, France, $313 \mathrm{p}$.

HESSEN D.O., AGERBERG A., KJELLBERG G., ODELSTRØM T., WESTMAN K., 1989. Food, nutrition, growth, reproduction and genetics. In: SKURDAL J., WESTMAN K. and BERGAN, P.I. (Eds.). Crayfish culture in Europe. Report from the Workshop on Crayfish Culture. 16-19 november, 1987, Trondheim, Norway, 39-48.

INGLE R.W., 1977. Laboratory and SCUBA studies on the behaviour of the freshwater crayfish Austropotamobius pallipes (Lereboullet). Rep. Underwater Ass. 2(NS), 115.

MATTHEWS M.A., 1992. Reproduction, growth and aquaculture potential of the freshwater crayfish Austropotamobius pallipes (Lereboullet). PhD. Thesis, University of Dublin, Ireland, $222 \mathrm{p}$.

PURSIAINEN M., JÄRVENPÄÄ T., TULONEN J., WESTMAN K., 1989. Crayfish culture in Finland. In: SKURDAL J., WESTMAN K. and BERGAN, P.I. (Eds.). Crayfish culture in Europe. Report from the Workshop on Crayfish Culture, 16-19 Nov. 1987, Trondheim, Norway, pp. 69-78.

REYNOLDS J.D., CELADA J.D., CARRAL J.M., MATTHEWS M.A., 1992. Reproduction of astacid crayfish in captivity-current developments and implications for culture, with special reference to Ireland and Spain. Invertebr. Reprod. Dev., 22 (1-3), 253-266.

RHODES C.P., HOLDICH D.M., 1982. Observations on the fecundity of the freshwater crayfish Austropotamobius pallipes in the British Isles. Hydrobiologia, 89, 231236.

SVENSSON M., GYDEMO R., 1997. Mating capacity in male noble crayfish, Astacus astacus, under laboratory conditions. Freshwater Crayfish, 11, 311-318.

TAUGBØL T., SKURDAL J., 1990. Effect of density on brood size in noble crayfish in noble crayfish, Astacus astacus L., subjected to indoor rearing conditions. Aquaculture and Fisheries Management, 21, 17-23.

WOODLOCK B., 1985. Breeding and fecundity in the crayfish Austropotamobius pallipes (Lereboullet). B.A. Thesis, Dept. of Zoology, University of Dublin, Ireland, 79 p.

WOODLOCK B., REYNOLDS J.D., 1988. Laboratory breeding studies of freshwater crayfish Austropotamobius pallipes (Lereboullet). Freshw. Biol., 19 (1), 79-86. 